\title{
KEKERABATAN 22 KLON BAWANG MERAH BERDASARKAN MARKA MIKROSATELIT Genetic Relationship off 22 Shallot Clones Base on Microsatelit Marker
}

\author{
Joko Pinilih, Meddy Rachmadi, Murdaningsih HK, dan Warid Ali Qosim \\ Universitas Gadjah Mada \\ email korespondensi: publikasi@pasca.unpad.ac.id
}

\begin{abstract}
Abstrak
Bawang merah merupakan komoditas sayuran penting di Indonesia. Tujuan penelitian adalah untuk mempelajari hubungan kekerabatan 22 klon bawang merah. Penelitian dilaksanakan di Balai Besar Penelitian Biteknologi dan Sumber Daya Genetik Pertanian di Bogor. Penelitian dilakukan pada bulan Oktober sampai dengan bulan Desember 2013. Hasil penelitian menunjukkan bahwa Tingkat kemiripan genetik (genetic similarity) dari 22 genotipe yang diuji berkisar antara 0,75 - 0,99, halini berarti diantara ke-22 genotipe mempunyai kekerabatanyang dekat.
\end{abstract}

\begin{abstract}
Shallot is important vegetable crops in Indonesia. The aim of research to study genetic relationship of 22 clones shallot with microsatellite molecular markers. Research was conducted at the Research Institute Biotechnology and Agricultural Genetic Resources in Bogor. The study was conducted in October to December, 2013. The results of research showed the genetic similarity of 22 genotypes were closely relationship obout 0.75 to 0.99 .
\end{abstract}

\section{PENDAHULUAN}

Bawang merah merupakan salah satu komoditas sayuran dataran rendah. Komoditas ini bukan merupakan kebutuhan pokok, namun hampir selalu dibutuhkan oleh konsumen rumah tangga sebagai pelengkap bumbu masak sehari-hari. Kegunaan lain dari bawang merah adalah sebagai obat tradisional (sebagai kompres penurun panas, diabetes, penurun kadar gula dan kolesterol darah, mencegah penebalan dan pengerasan pembuluh darah dan maag) karena bawang merah mengandung senyawa allin dan allisin yang bersifat bakterisida (Soetiarso dan Setiawati, 2005). Pesatnya peningkatan industri pengolahan makanan juga cenderung meningkatkan kebutuhan bawang merah di dalam negeri sebesar kurang lebih 5\% setiap tahunnya di luar konsumsi untuk restoran, hotel dan industri olahan (Pasaribu dan Daulay, 2013).

Untuk kepentingan persilangan diperlukan adanya keragaman genetik. Keragaman genetik tersebut biasanya diperoleh dari varietas lokal, varietas hasil pemuliaan, introduksi dan klon klon hasil persilangan. Untuk memperkaya keragaman bawang merah dilakukan dengan cara eksplorasi ke daerah daerah sentra produksi bawang merah (Kusandriani, 2008). Dari koleksi materi tersebut kemudian dilakukan persilangan guna menghasilkan kergaman genetik pada bawang merah untuk kepentingan seleksi pada program pemuliaan tanaman bawang merah. Pada bawang merah sudah sering dilakukan persilangan untuk merakit varietas baru yang unggul. Seleksi hasil persilangan akan efektif jika populasi yang diseleksi mempunyai keragaman genetik yang luas (Syukur dkk, 2015).

Untuk mengetahui hubungan kekerabatan 22 klon bawang merah tersebut maka perlu dilakukan analisis kekerabatan. Karakterisasi terhadap 22 klon bawang merah tersebut perlu dilakukan menganalisis kekerabatan antar klon-klon tersebut. Pelaksanaan kegiatan tersebut mengacu pada pedoman yang ditetapkan oleh lembaga Internasional untuk sumber daya genetik tanaman (IBPGR, 1992; Chaudhry, et al., 1995).

Karakterisasi dapat dilakukan secara morfologi dan atau dengan marka molekuler. Untuk mengetahui kekerabatan 22 klon bawang merah tersebut dapat diidentifikasi dengan menggunakan marka molekuler. Marka ini sudah banyak digunakan untuk identifikasi berbagai tanaman diantaranya yaitu karakterisasi plasma nutfah padi beras merah asal propinsi DIY (Utami dkk, 2009), marka mikrosatelit sebagai alternatif uji BUSS dalam perlindungan tanaman padi (Muljopawiro, 2007).

Pada penelitian ini akan digunakan penanda mikrosatelit atau simple sequence repeat (SSR )untuk menganalisis kekerabatan 22 klon bawang merah. Mikrosatelit adalah sekuen sederhana yang berulangulang yang melimpah dalam genom suatu spesies. Mikrosatelit memiliki pengulangan sekuen yang berurutan dua sampai 4 motif sekuen nukleotida sebagai sekuen konservatif. Marka ini sangat berguna sebagai marka genetik karena bersifat : kodominan, sehingga dapat mendeteksi keragaman alel pada level yang tinggi, mudah dan ekonomis dalam pengaplikasiannya karena menggunakan proses PCR (Tasliah dkk, 2013).

Analisis kekerabatan terhadap 22 klon bawang merah ini akan berguna dalam program pemuliaan bawang merah terutama dalam pemilihan tetua persilangan. Dari analiss kekerabatan tersebut akan diperoleh jarak genetik di antara 22 klon bawang merah tersebut. Persilangan antara tetua yang mempunyai jarak genetik berjauhan akan menghasilkan variabilitas genetik yang luas pada keturunannya.

\section{METODE}

Materi penelitian meliputi 22 klon bawang merah. Sampel untuk uji marka mikrosatelit, diambil dari 22 klon bawang merah yang ditanam di lapangan. Daftar klon - klon yang akan diuji dapat dilihat pada Tabel 1. Primer yang digunakan untuk uji marka molekuler dapat dilihat pada Tabel 2. Penelitian uji kekerabatan dengan marka mikrosatelit dilaksanakan di Balai Besar Penelitian Biteknologi dan Sumber Daya Genetik Pertanian di Bogor. Penelitian dilakukan pada bulan Oktober sampai dengan bulan Desember 2013. 
DNA bawang diisolasi dari jaringan daun yang segar mengikuti metode isolasi DNA Van Heusden et al.. (2000). Bufer isolasi (BI) DNA yang digunakan terdiri dari tiga komponen, yaitu bufer lisis, bufer ekstraksi, dan sarkosyl 5\% dengan rasio 2.5:2.5:1. Bufer lisis terdiri dari 0.2M TRIS- $\mathrm{HCl}$ pH 7.5, 0.05M EDTA, $2 \mathrm{M} \mathrm{NaCl}$, $2 \%(\mathrm{w} / \mathrm{v}) \mathrm{CTAB}$, sedangkan bufer ekstraksi mengandung $0.35 \mathrm{M}$ sorbitol, $0.1 \mathrm{M}$ TRIS- $\mathrm{HCl}, \mathrm{pH}$ 7.5, $5 \mathrm{mM}$ EDTA. Sekitar $0.25 \mathrm{~g}$ daun segar dimasukkan ke dalam tabung mikro berukuran $2 \mathrm{ml}$, dibekukan, dan digerus dengan bantuan nitrogen cair. Sebanyak $750 \mu$ l bufer isolasi (BI) DNA yang mengandung $\mathrm{Na}_{2} \mathrm{~S}_{2} \mathrm{O}_{5}(3.8 \mathrm{~g} / \mathrm{I})$ ditambahkan ke dalam hasil gerusan dan campuran tersebut diinkubasi selama 1 jam pada penangas air $65^{\circ} \mathrm{C}$. Selama proses inkubasi, tabung dibolak-balik secara perlahan setiap 15 menit guna menyempurnakan proses inkubasi. Selanjutnya DNA dipurifikasi dengan menambahkan $750 \mu \mathrm{l}$ chloroform/isoamylalcohol (24:1) dan dicampur secara merata dengan cara membolak-balik tabung (10-20 kali). Kemudian suspensi disentrifugasi pada kecepatan 14000 rpm selama 5 menit dan supernatan dipindahkan ke dalam tabung mikro yang baru.

Tabel 1. Klon Klon Bawang Merah yang diuji

\begin{tabular}{|l|l|l|}
\hline NO KLON & KLON & ASAL KLON \\
\hline G1 & KL 1039 & Bauji X F10 \\
G2 & KL 1031 & Bauji X Tiron \\
G3 & KL 1041 & Bauji X Maja \\
G4 & KL 1047 & Kuning X Maja \\
G5 & KL 1050 & Kuning X Tiron \\
G6 & KL 1018 & Kuning X F10 \\
G7 & KL SS-5 & Bima X Tiron \\
G8 & KL N5 & Bima X katumi \\
G9 & Bima & Lokal Brebes \\
G10 & KL 1116 & Tiron X Maja \\
G11 & KL 1136 & Bima X Mentes \\
G12 & KL 1152 & Bauji X kuning \\
G13 & Pikatan & Kuning X thailand \\
G14 & Maja & Lokal Maja \\
G15 & F 130 & Bima X India \\
G16 & KL 1152 & Tiron X F10 \\
G17 & Sumenep & Lokal sumenep \\
G18 & JK 88 & Bima X Bali Karet \\
G19 & JK 80 & Bima X Mentes \\
G20 & Super Philips & introduksi \\
G21 & JK 66 & Kuning X Bauji \\
G22 & Katumi & Bima X Super Philips \\
\hline
\end{tabular}

Analisis PCR dilakukan dengan total reaksi $20 \mu \mathrm{l}$ mengandung 25 ng DNA genomik cetakan, masingmasing dNTP $0.1 \mathrm{M}$ (dATP, dCTP, dGTP, dan dTTP), masing-masing primer $0.25 \mathrm{uM}$, enzim Taq DNA polymerase 1 unit dalam larutan buffer $1 X$ (FastStart, produk Roche). Reaksi amplifikasi dilakukan berdasarkan metode (Masuzaki et al., 2006) menggunakan mesin PCR MJ Research PCT-100. Program PCR terdiri dari tahapan pre-denaturasi pada suhu $94^{\circ} \mathrm{C}$ selama 3 menit, dilanjutkan dengan 35 siklus denaturasi pada suhu $94^{\circ} \mathrm{C}$ selama 30 detik, annealing pada suhu $50-60^{\circ} \mathrm{C}$ selama 45 detik, dan ekstension $72^{\circ} \mathrm{C}$ selama 45 detik. Pada tahap terakhir proses PCR dilakukan ekstension akhir pada suhu $72^{\circ} \mathrm{C}$ selama 5 menit. Produk PCR diseparasi dengan teknik elektroforesis pada poliakrilamid $6 \%$. Sebanyak 3 ul produk PCR dan 1 ul loading dye beserta 100-bp DNA ladder sebagai marker (invitrogen) dimasukkan ke dalam masing-masing sumuran gel dan diseparasi dengan arus sebesar 60-100 volt selama 1-1.5 jam. Selanjutnya DNA distaining (diwarnai) dengan merendam gel dalam larutan ethidium bromide (1 $\mathrm{mg} / \mathrm{L})$ selama 10-20 menit dan fragmen DNA hasil amplifikasi divisualisasi di bawah sinar UV dan didokumentasi dengan bantuan alat Chemi-doc transluminator.

Pada uji marka mikrosatelit analisis data akan dilakukan berdasarkan hasil skoring pola pita DNA yang muncul pada gel poliakrilamid. Hasil skoring dalam bentuk data biner, jika ada pita diberi skor 1 dan jika tidak ada pita diberi sekor 0 . Data hasil pengamatan yang telah diperoleh kemudian dianalisis dengan menggunakan program atau sofware NTSYS-pc versi 2.1. Dari analisis data tersebut selanjutnya akan dihasilkan dendogram. Dari dendogram tersebut kemudian dapat diketahui pola hubungan kekerabatan 22 klon bawang merah. Jarak genetik dihitung dengan rumus $S=1-G S$, dimana $S$ : jarak genetic dan GS : Kemiripan genetik (Genetic Similarity).

\begin{tabular}{|c|c|c|c|}
\hline bh & Primer & Forward (5-3) & Reverse (5-3) \\
\hline 1 & AMS02 & GCATTAACTATCTAAAACATTG & CCATCAACTCATAACAGGT \\
\hline 2 & AMS03 & TAACCCTAGGATGAGTTGAG & GGATTTCCTCTTGAGATGA \\
\hline 3 & AMS04 & TATGTTTTCAGCTGCGATGTGAG & AAATCTAAGCACGGATACCAAGTG \\
\hline 4 & AMS06 & GGTGCATAGGGTCTCATCTG & ATTGATTGTTTGTTTGGATGTG \\
\hline 5 & AMS07 & TGCGAATGTGAGGTTTTCTGC & CGACCCGGAAATTTCGATC \\
\hline 6 & AMS08 & GCCACGATGTTGAGATTTCG & CCCGAATATCCCACCAGTTC \\
\hline 7 & AMS09 & ACAACTTTCAATTGCATTC & CGTGGACTAACTTACTATCTATC \\
\hline 8 & AMS10 & TTCATGTTGTATTGAGATTTGG & GAAGGAATGGAAGCAGTTC \\
\hline 9 & AMS12 & AATGTTGCTTTCTTTAGATGTTG & TGCAAAATTACAAGCAAACTG \\
\hline 10 & AMS13 & ACCTTTTAAATTGACGATATTCC & CTGCACTATCTCGTGATGTATTTC \\
\hline 11 & AMS14 & CCCCTGAGTAAATTCAAAATCC & TCCTTAGTATAATTTCGGGGTAAC \\
\hline 12 & AMS16 & CTGCATTAAAACAACCAAACTTG & GAGCTCCACTTCTTCCAAACTAG \\
\hline 13 & AMS17 & AGTGGACTCAAGGCAGATG & ATCACCATTCACCGTTTACT \\
\hline 14 & AMS18 & ACTCGGGTGTTATTCCAT & CCAATCAGACATACCATACAATC \\
\hline 15 & AMS19 & GCTCTGATACCAAATGTAACGA & CGAATGTGAGGTTTTCTGC \\
\hline 16 & AMS21 & GGTTGTTTCCACTACACTTGAG & CGTCCTTGGTATTCTTGTGC \\
\hline 17 & AMS23 & GCTGTTCACTGGTCTATCTGG & ATTCGGTGCTGATTTTCG \\
\hline 18 & AMS25 & GAGGGCAGTGTTAGCATTCC & GCAACCTTTCCCCGAGAG \\
\hline 19 & AMS26 & ATCTAATCAAAGCATAGTTG & TTGTCCAAGTAGTTGTGA \\
\hline 20 & AMS28 & GTTGTCCTTTGCGTTTAC & ATGGTTTCATCAATGTCC \\
\hline
\end{tabular}

\section{HASIL DAN PEMBAHASAN}

Pada analisis kekerabatan 22 klon bawang merah ini bertujuan untuk mengetahui pola hubungan kekerabatan antar klon - klon tersebut. Dari 22 klon tersebut terdiri atas hasil - hasil silangan dan lima klon bawang merah merupakan varietas yang sudah dilepas. Empat klon diantara lima klon tersebut merupakan tetua persilangan. Empat klon tersebut adalah Bima, bauji, kuning dan Maja. Sedangkan Sumenep tidak digunakan untuk tetua persilangan karena klon tersebut tidak bisa berbunga. Dengan demikian pada - 
analisis kekerabatan ini dapat diketahui juga hubungan kekerabatan antara tetua dan keturunannya. Analisis kekerabatan berguna untuk mengetahui pola pengelompokan genotip dari 22 klon bawang merah yang di analisis. Hasil pengelompokan dapat digunakan sebagai dasar untuk memilih tetua persilangan. Tetua persilangan yang dapat digunakan adalah yang berkerabat jauh yang diharapkan dapat menghasilkan keturunan dengan variabilitas genetik yang besar. Jika tetua persilangan berkerabat dekat maka akan menghasilkan keturunan dengan variabilitas genetic yang sempit bahkan bisa terjadi inbreeding.

Setelah mendapatkan DNA 22 klon bawang merah yang sudah diisolasi tahapan selanjutnya adalah amplifikasi PCR dengan menggunakan 20 primer. Reaksi amplifikasi dilakukan berdasarkan metode (Masuzaki et al., 2006) menggunakan mesin PCR MJ Research PCT100. Produk PCR diseparasi dengan teknik elektroforesis pada poliakrilamid 6\%. Hasil elektroforesis kemudian divisualisasi di bawah sinar UV dan didokumentasi dengan bantuan alat Chemi-doc transluminator. Hasil dokumentasi elektroforesis pada gel poliakrilamid dapat dilihat pada Gambar 1.

DNA yang sudah melalui proses elektroforesis akan menghasilkan pita - pita DNA yang muncul atau terlihat pada gel poliakrilamid. Pita-pita tersebut di dinilai atau diskor dan hasil skoring berupa data biner dengan nilai 1 dan 0 . Data hasil skoring kemudian dianlisis dengan program atau sofware NTSYS-pc versi 2.1. Dari analisis tersebut akan didapatkan dendogram. Dendogram tersebut kemudian dipakai untuk analisis kekerabatan 22 klon bawang merah. Dendogram hasil analisis data dari 22 klon bawang merah yang diuji dapat dilihat pada Gambar.2.

Hasil dendrogram menunjukkan hampir semua genotip dapat dibedakan antara satu genotip dengan genotip lainnya. Dari dendogram tersebut maka ke 22 genotip tersebut bisa dikelompokkan. Melalui dendogram yang tebentuk bila ditarik garis memotong pada sekala tingkat kekerabtan 0,83 maka akan

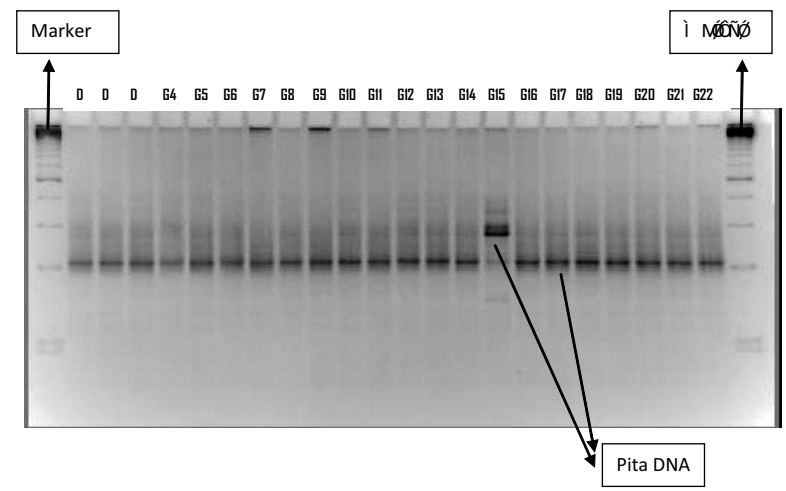

Gambar 1. Visualisasi pola pita DNA pada 22 klon bawang merah dengan penanda mikrosatelit terbentuk dua kelompok atau kluster dan satu genotip yang berdiri sendiri. Kluster I terdiri atas 13 genotip yaitu genotip $\mathrm{G} 1, \mathrm{G} 2, \mathrm{G} 3, \mathrm{G} 12, \mathrm{G} 10, \mathrm{G} 16, \mathrm{G} 17, \mathrm{G} 4, \mathrm{G} 13$, G5,G 21,G6 dan G14. Kluster II terdiri atas 8 genotip yaitu genotip G7, G8, G11, G20, G22, G9, G18 dan G19. Sedangkan genotip yang berdiri sendiri adalah genotip G15.

Tingkat kemiripan genetik (genetic similarity) dari 22 genotipe yang diuji berkisar antara 0,75-0,99, hal ini berarti diantara ke-22 genotipe mempunyai kekerabatan yang dekat. Nilai tingkat kemiripan genetik ini dapat dilihat pada tabel 3. Nilai kemiripan genetik merupakan nilai yang menunjukkan diantara genotip genotip yang diuji.

Hasil analisis kekerabatan 22 genotip bawang merah ini ternyata berbeda dengan tanaman lain misalnya tanaman shorgum. Pengujian kekerabatan terhadap shorgum telah dilakukan oleh (Dualembang, 2012) yang hasilnya nilai kemiripan genetiknya atau tingkat kekerabatannya sebesar 0,15 - 0,90. Artinya dari genotip - genotip shorgum yang dianalisis hubungan kekerabatannya ternyata mempunyai hubungan kekerabatan dari dekat sampai jauh. Tanaman shorgum yang dianalisis kekerabatannya tersebut mempunyai variabillitas genetik yang luas. Hal ini menguntungkan bagi kegiatan pemuliaan tanaman. Hal sebaliknya terjadi pada bawang merah yang semua genotipnya berkerabat dekat sehingga akan kesulitan untuk memilih tetua persilangan dalam rangka mempeoleh varietas baru. Diantara klon - klon bawang merah mempunyai tingkat kekerabatan yang dekat diduga dikarenakan bawang merah yang dibudidayakan di Indonesia di kembangbiakkan secara vegetatiif sehingga sulit terjadi variasi diantara varietas - varietas bawang merah yang ada di Indonesia.

Berdasarkan hubungan kekerabatan diantara 22 genotip maka diperoleh kisaran nilai jarak genetik $0,01-0,32$. Nilai jarak genetik selengkapnya dapat dilihat pada matrik jarak genetik pada tabel 3. Nilai

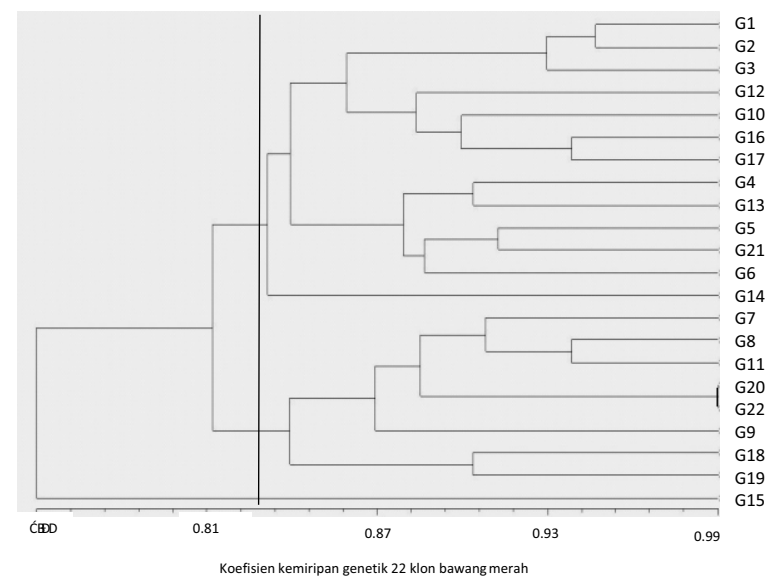

Gambar 2. Dendogram 22 Klon bawang merah berdasarkan kemiripan genetik 
jarak genetik tersebut tergolong rendah yang artinya variabilitas genetic dari 22 genotip tersebut sempit. Pasangan genotip paling berkerabat dekat adalah genotip 20 dan genotip 22 yang mempunyai nilai jarak genetik 0,01 . Sedangkan pasangan genotip yang paling berkerabat jauh adalah genotip G15 dan genotip 22 yang mempunyai nilai jarak genetik 0,32. Namun kisaran nilai jarak genetik 22 genotip bawang merah tersebut bagaimanapun juga tergolong kecil sehingga apabila individu - individu tersebut disilangkan tidak akan didapatkan keragaman genetik yang luas pada keturunannya. Hal ini pastinya akan menyulitkan pemulia untuk merakit varietas baaru bawang merah.

Tabel 3. Matrik Kemiripan Genetik 22 Klon Bawang Merah

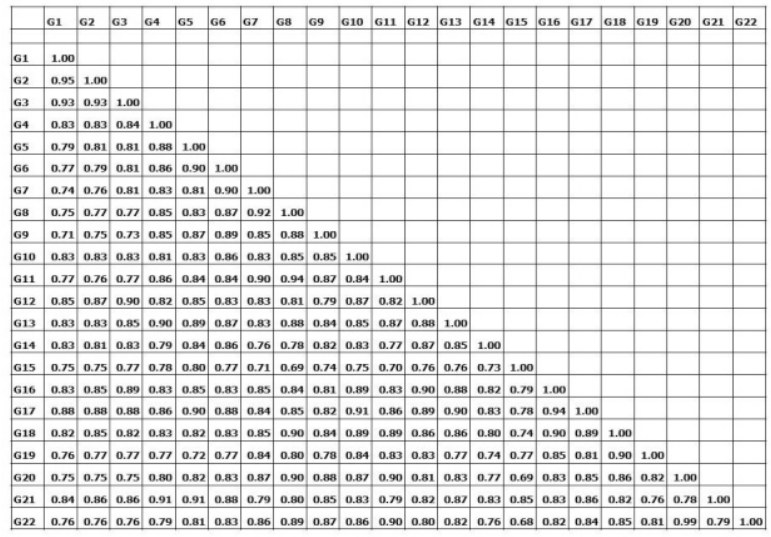

Nilai jarak genetik perlu diperhatikan karena dapat dipakai acuan untuk melakukan persilangan. Pasangan genotip yang berkerabat dekat yang ditandai dengan nilai jarak genetic yang kecil dihindari untuk disilangkan karena kalao dipaksakan tidak akan mendapatkan keragaman yang cukup pada keturunannya atau bahkan terjadi inbreeding. Pabendon et al. (2007), menyatakan pasangan genotip baik untuk disilangkan apabila mempunyai jarak genetik lebih dari 0,7. Oleh karena itu analisis kekerabatan sangat penting untuk program pemuliaan tanaman.

Tabel 4. Matrik Jarak Genetik 22 Klon Bawang Merah

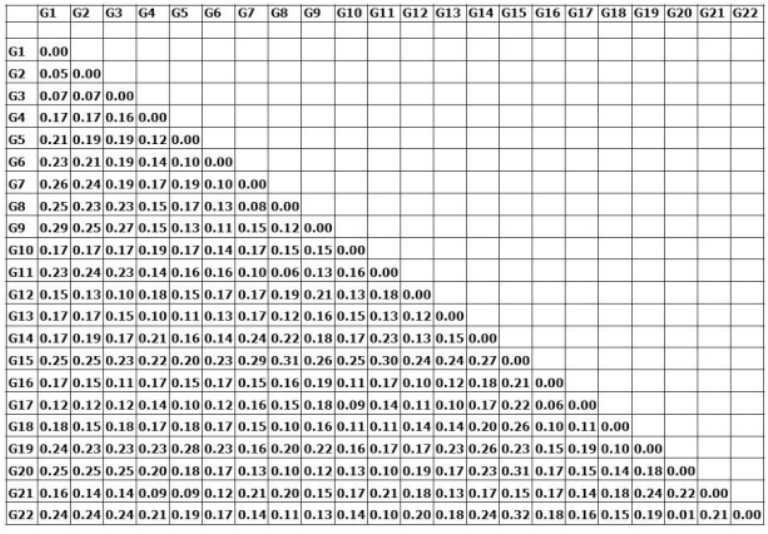

Bila dilihat kembali pada penelitian ini masih terdapat pasangan persilangan yang kedua tetuanya masih berkerabat dekat. Sebagai contoh klon G5 yang merupakan hasil persilangan antara Bima dengan katumi. Berdasarkan hasil analisis kekerabatan Bima dengan Katumi mempunyai jarak genetik 0,13 dan masih berada dalam satu klaster. Demikian juga klon no 22 yang merupakan hasil persilangan antara Super
Philip dengan Bima. Bima dengan Super Philip mempunyai jarak genetik 0,12 dan juga masih dalam satu klaster.

Setelah melihat hasil analisis kekerabatan 22 klon bawang merah yang menunjukkan berkerabat dekat maka program pemuliaan bawang merah ke depan yang harus dilakukan adalah memperluas keragaman genetik. Usaha perluasan keragaman genetik dapat dilakukan dengan menggunakan tetua persilangan yang berkerabat jauh misalnya bawang bombai. Perluasan keragaman genetik juga bisa dilakukan dengan persilangan antar spesies misalnya menyilangkan bawang merah dengan bawang daun.

\section{SIMPULAN}

1. Kekerabatan 22 klon bawang merah sangat dekat yang ditandai dengan nilai kemiripan genetik yang tinggi yaitu $0,75-0,99$.

2. Pasangan genotip yang mempunyai hubungan kekerabatan paling jauh adalah klon G15 dengan klon 22 yaitu dengan nilai jarak genetik 0.32 .

3. Untuk meningkatkan keragaman genetik bawang merah dapat dilakukan dengan persilangan dengan yang berkerabat jauh atau dengan persilangan antar spesies.

\section{DAFTAR PUSTAKA}

Dualembang, E, Yunus Musa dan M. Azrai, 2012. Karakterisasi Genetik Koleksi Plasma Nutfah Sorgum (Sorghum bicolor L) Berbasis Marka SSR.

Chaudhry, M. N.A. Iqbal and M. C. Sodiq. 1995. Screening of germplasm against insect pests of brinjal crop. capsicum and eggplant Newsletter.No.14:82-85.

IBPGR. 1992. Buckwheat genetic in East Asia. Paper of an IBPGR Workshop, Ibaraki, Japan. International Crop Network Series No.6. International Board for Plant Genetic Resources, Rome.

Kusandriani. Y, 2008. Koleksi, Karakterisasi, praevaluasi dan konservasi Plasma Nutfah Sayuran untuk Pemanfaatan dan Pengembangan Bank Genetik. Laporan Hasil Penelitian Balitsa.

Masuzaki, S., Araki, N., Yamauchi, N., Yamane, N., Wako, T., Kojima, A. and Shigyo, M. (2006) Chromosomal locations of microsatellites in onion. Hortscience 41, 315-318.

Moeljopawiro.S. 2007. Marka Mikrosatelit sebagai AlternatifUji BUSS dalam Perlindungan Varietas Tanaman Padi. Zuriat 18(2).

Pabendon, M.B., Mejaya M.J., Koswara.J., dan Aswidinnoor H. 2007. Analisis KeragamanGenetik Inbrida Jagung Berdasarkan Marka SSR dan Korelasinya dengan Data Fenotipik F1 Hasil Silang Uji. Jurnal Penelitian Pertanian Tanaman Pangan Vol. 26 No. 2.

Pasaribu, T. W dan Murni Daulay, 2013. Analisis Permintaan Impor Bawang Merah, vol.2, No $1: 32-37$

Soetiarso, T. A dan Wiwin Setiawati. 2005. Pedoman Umum Pengembangan Teknologi Inovatif pada Tanaman Bawang Merah. Balai Penelitian Tanaman Sayuran.

Syukur, M, Sriani Sujiprihati dan Rahmi Yuninati. 2015. Teknik Pemuliaan Tanaman. Edisi Revisi. Panebar Swadaya. 348p.

Tasliah, H. Rijzaani, T. Z.P. Hariyadi, Siti Yuriyah, Rebin, Ma'sumah, dan T. S. Silitonga. 2013. Analisis Keragaman Genetik 161 Aksesi Mangga Indonesia Menggunakan Marka Mikrosatelit. AgroBiogen 9(3):125-134

Utami,W.D, Kristantini dan Prajitno. 2009. Karakterisasi Plasma Nutfah Padi berasmerah Lokal Asal Provinsi daerah Istimewa Yogyakarta Berdasarkan Morfo Agronomi dan Marka SSRs. Zuriat: 20(1). 